\title{
ANALISIS PENDAPATAN USAHATANI KAKAO DI DESA TIKONG, KECAMATAN TALIABU UTARA, KABUPATEN KEPULAUAN SULA
}

\author{
Rosneni La Jauda \\ O. Esry H. Laoh \\ Jenny Baroleh \\ Jean F.J. Timban.
}

\begin{abstract}
This study aims to determine the amount of income from farming cocoa farmers in the village of Tikong, Sub-district of North Taliabu, Sula Islands District. Data analysis method used is the analysis of cost, revenue and income. The results showed that the income of cocoa farmers which have land area of 0.5 to $1,5 \mathrm{Ha}$ is $\mathrm{Rp} 2,392,749$ and income of cocoa farmers who have land area of $>1.5$ to 2 hectares is $R p$ 2,766,69. In an effort to increase the income of the farming activities of cocoa, farmers in the village of Tikong were trying to increase the production and the size of the land. in order to increase their income.
\end{abstract}

Keywords: the income of cocoa farmers, land size, production, Tikong village, Sula Island District

\begin{abstract}
ABSTRAK
Penelitian ini bertujuan untuk mengetahui besarnya pendapatan petani dari usahatani kakao di Desa Tikong, Kecamatan Taliabu Utara, Kabupaten Kepulauan Sula. Metode analisis data yang digunakan adalah analisis biaya, penerimaan dan analisis pendapatan. Hasil penelitian menunjukan bahwa pendapatan petani kakao di Desa Tikong yang memiliki luas lahan 0,5 - 1,5 Ha adalah sebesar Rp 2.392.749 dan pendapatan petani kakao yang memiliki luas lahan >1,5 - 2 Ha adalah sebesar Rp 2.766.698. Dalam usaha meningkatkan pendapatan dari kegiatan usahatani maka petani kakao di Desa Tikong berusaha untuk meningkatkan produksi. Karena pendapatan mereka akan cenderung naik sejalan dengan bertambahnya produksi dan besarnya suatu lahan.
\end{abstract}

Kata kunci: pendapatan petani Kakao, luas lahan, produksi, Desa Tikong, Kabupaten Kepulauan Sula

\section{PENDAHULUAN}

\section{Latar belakang}

Indonesia adalah Negara agraris dengan kekayaan alam yang melimpah serta masyarakat yang didominasi oleh petani yang bergantung hidup pada sektor pertanian.Pertanian muncul pada manusia mulai mengendalikan pertumbuhan tanaman dan hewan serta mengaturnya sedemikian rupa sehingga menguntungkan.Pembangunan pertanian adalah suatu proses untuk meningkatkan hasil produksi usahatani (Hanafi, 2010).

Pertanian adalah kegiatan pemanfaatan sumberdaya hayati yang dilakukan manusia untuk menghasilkan bahan pangan, bahan baku industri atau sumber energi, serta untuk mengelola lingkungan hidup. Kegiatan pemanfaatan sumberdaya hayati yang termasuk dalam pertanian biasa di pahami orang sebagai budidaya tanaman atau bercocok tanam serta pemanfaatan mikroorganisme danbioenzim dalam pengolahan produk lanjutan seperti pembuatan keju, tahu, tempe atau sekedar ekstraksi semata seperti penangkapan ikan atau ekploitasi hutan, sektor pertanian merupakan sektor terbesar di Indonesia.Ditunjang dengan wilayah yang sangat luas dan kekayaan alam yang melimpah salah satunya adalah tanaman kakao memegang pernan penting bagi seluruh masyarakat (Yrama, 2010).

Tanaman Kakao banyak ditanam oleh masyarakat Kabupaten Kepulauan Sula sebagai tanaman budidaya. Sebagian besar petani kakao di Desa Tikong hanya mendapat keahlian 
bercocok tanam yang diwariskan. Seperti umumnya wilayah Kepulauan Maluku, Kepulauan Sula merupakan Daerah perkebunan yang menghasilkan kelapa, cengkeh dan kakao. Tanaman kakao banyak ditanam di Pulau Taliabu khususnya di Kecamatan Taliabu Utara dengan luas 14.282,00 $\mathrm{Ha}$ dan produksi 3.542,14 Ton/Tahun (http://Bab_ II_ Profil_ Umum_Kab_Kep_Sula. pdf. 21 Juni2014 ).

Desa Tikong merupakan salah satu Desa yang banyak terdapat pohon kakao dan banyak menanam tanaman kakao dibanding dengan Desa- Desa yang lain. Sebagian besar penduduk bermata pencarian sebagai petani. Hasil yang diproduksi biasanya untuk dijual dengan tujuan untuk meningkatkan pendapatan keluarga.

\section{Deskriptif Tanaman Kakao}

Tanaman kakao merupakan tanaman yang menumbuhkan bunga dari batang atau cabang. Untuk itulah tanaman kakao digolongkan menjadi kelompok tanaman Caulifloris, adapun sistematika tanaman kakao menurut klasifikasi secara botani adalah:

$\begin{array}{ll}\text { Divisi } & \text { : Spermatophyta } \\ \text { Sub divisi } & \text { : Angiospermae } \\ \text { Class } & \text { : Dicotiledoneae } \\ \text { Ordo } & \text { : Malvales } \\ \text { Famili } & \text { :Sterculiceae } \\ \text { Genus } & \text { :Theobroma } \\ \text { Species } & \text { : Theobroma cacao L }\end{array}$

\section{Pengertian Usahatani}

Usahatani adalah kegiatan usaha manusia untuk mengusahakan tanahnya dengan maksud untuk memperoleh hasil tanaman atau hewan tanpa mengakibatkan berkurangnya kemampuan tanah yang bersangkutan untuk memperoleh hasil selanjutnya. Pendapatan kotor usahatani atau penerimaan usahatani sebagai nilai produksi total usahatani dalam jangka waktu tertentu baik yang dijual maupun tidak dijual. Untuk menaksir komoditi atau produk yang tidak dijual, digunakan nilai berdasarkan harga pasar yaitu dengan cara mengalikan produksi dengan harga pasar.

\section{Pengertian Penerimaan}

Penerimaan usahatani adalah nilai produk total usahatani dalam jumlah tertentu yang dijual,diberikan kepada orang lain yang dikomsumsi dan diperoleh dari jumlah produk secara keseluruhan dikalikan dengan harga yang berlaku ditingkat petani Soekartawi (1995).

Penerimaan (TR) adalah banyaknya produksi total dikalikan dengan harga peneriamaan total diformulasikan sebagaiberikut :

$$
\mathrm{TR}=\mathrm{P} \text { X Q }
$$

\section{Dimana:}

TR $($ Total Revenue $)=$ Total Penerimaan

$\mathrm{P}($ Price $)=$ HargaProduk $(\mathrm{Rp})$

$\mathrm{Q}($ Quantity $)=$ Jumlah Produk (Unit)

\section{Pengertian Biaya}

Menurut Sukirno(2006), biaya produksi didefinisikan sebagai semua pengeluaran yang dilakukan oleh perusahaan untuk memperoleh faktor-faktor produksi dan bahan-bahan mentah yang akan digunakan untuk menciptakan barang - barang yang diproduksi perusahaan tersebut.

\section{Total Cost (TC)}

Keseluruhan jumlah biaya produksi yang dikeluarkan dinamakan biaya total. Biaya produksi total atau total biaya didapat dari menjumlahkan biaya tetap total (total fixed cost) dan biaya variable total (total variable cost). Dengan demikian biaya total dapat dihitung dengan menggunakan rumus berikut :

$$
\mathrm{TC}=\mathrm{TFC}+\mathrm{TVC}
$$

\section{Total Fixed Cost (TFC)}

Keseluruhan biaya yang dikeluarkan untuk memperoleh faktor produksi (input) yang tidak dapat diubah jumlanya dinamakan biaya tetap total. Contoh biaya tetap adalah penyusutan peralataan usaha yang dihitung menggunakan rumus sebagai berikut (Bambang dkk, 2011).

$$
\Sigma=\frac{\text { Penyusutan harga beli }}{\text { Umur Ekonomis }}
$$

\section{Total Variabel Cost (TVC)}

Keseluruhan biaya yang dikeluarkan untuk memperoleh faktor produksi yang dapat diubah jumlahnya dinamakan biaya variable cost. Contoh biaya variable adalah biaya bahan baku.

\section{Pengertian Pendapatan}

Pendapatan merupakan salah satu indikator untuk mengukur kesejahteraan seseorang atau 
masyarakat, sehingga pendapatan masyarakat ini mencerminkan kemajuan ekonomi suatu masyarakat. Menurut Sukirno (2000), pendapatan individu merupakan pendapatan yang diterima seluruh rumah tangga dalam perekonomian dari pembayaran atas penggunaan faktor-faktor produksi yang dimilikinya dan dari sumber lain. Menurut Sukirno (2006) pendapatan adalah jumlah penghasilan yang diterima oleh penduduk atas prestasi kerjanya selama satu periode tertentu, baik harian, mingguan, bulanan maupun tahunan. Kegiatan usaha pada akhirnya akan memperoleh pendapatan berupa nilai uang yang diterima dari penjualan produk yang dikurangi biaya yang telah dikeluarkan.

Pendapatan adalah selisih antara penerimaan dengan pengeluaran total usahatani kakao.Pendapatan dirumuskan sebagai berikut :

Dimana :

$$
\mathrm{Pd}=\mathrm{TR}-\mathrm{TC}
$$

$$
\begin{aligned}
& \text { Pd }=\text { Pendapatan Usahatani } \\
& \text { TR }=\text { Total Penerimaan } \\
& \text { TC }=\text { Total Biaya }
\end{aligned}
$$

\section{Faktor-faktor yang mendukung Usahatani Tenaga Kerja}

Tenaga kerja adalah suatu faktor yang penting dalam membangun sebuah usaha. Menurut Moehar (2002). Tenaga kerja adalah suatu alat kekuatan fisik manusia yang tidak dapat dipisahkan dari manusia dan ditunjukan pada usaha.

Setiap proses produksi diperlukan tenagakerja yang cukup memadai. Tenaga kerja yang diperlukan perlu disesuaikan dengan kebutuhan sehinggajumlahnya optimal (Soekartawi, 2003 dalam Ray-ray, 2013).

\section{Modal}

Dalam usahatani modal merupakan barang ekonomi yang digunakan untuk memperoleh pendapatan dan untuk mempertahankan pendapatan keluarga tani. Modal dalam usahatani diklasifikasikan sebagai bentuk kekayaan, baik berupa uang maupun barang yang digunakan untuk menghasilkan sesuatu secara langsung ataupun tidak langsung dalam suatu proses produksi. Pembentukan modal bertujuan untuk meningkatkan produksi dan pendapatan usahatani serta menunjang pembentukan modal lebih lanjut. Modal diperlukan dalam usaha tanpa modal sudah pasti usaha tidak biasa dilakukan (Hanafie, 2010).

\section{Produksi}

Soekartawi (2002), produksi adalah suatu kegiatan yang mengubah input menjadi output. Kegiatan tersebut dalam ekonomi biasa dinyatakan dalam fungsi produksi.Analisis terhadap kegiatan produksi perusahaan dikatakan berada dalam jangka pendek apabila sebagian dari faktor produksi dianggap tetap jumlahnya (fixed input) sedangkan dalam jangka panjang semua faktor produksi dapat mengalami perubahan yang artinya bahwa setiap faktor produksi dapat ditambah jumlahnya kalau memang diperlukan.

\section{Pemasaran}

Pemasaran adalah suatu proses sosial yang didalamnya individu dan kelompok mendapatkan apa yang mereka butuhkan dan inginkan dengan menciptakan, menawarkan, dan secara bebas mempertukarkan produk yang bernilai dengan pihak lain. Sedangkan manajemen pemasaran adalah proses perencanaan dan pelaksanaan, pemikiran, penetapan harga, promosi serta penyaluran gagasan, barang dan jasa untuk menciptakan pertukaran yang memenuhi sasaran- sasaran individu dan organisasi (Soekartawi, 2002).

\section{Perumusan Masalah}

Kakao merupakan salah satu komoditi pertanian yang memiliki nilai ekonomi tinggi dilihat dari harga jual yang secara umum diusahakan oleh petani secara turun temurun. Namun petani yang mengusahakan tanaman ini masih bersifat tradisional dan berskala kecil. Bantuan besar pendapatan, diperoleh petani dari usahatani kakao di Desa Tikong Kecamatan Taliabu Utara Kabupaten Kepulauan Sula.

\section{Tujuan dan Manfaat Penelitian}

Penelitian ini bertujuan untuk mengetahui besarnya pendapatan yang di peroleh petani dari usahatani kakao. Penelitian ini diharapkan dapat berguna dan bermanfaat bagi berbagai pihak terutama masyarakat Desa Tikong Kecamatan Taliabu Utara dan bagi peneliti untuk menambah pengetahuan dan pengalaman. 


\section{METODOLOGI PENELITIAN}

\section{Metode Pengambilan Sampel}

Pengambilan sampel dalam penelitian ini dilakukan dengan cara sengaja. Jumlah petani responden yang diambil adalah 30 petani dibagi menjadi dua yaitu responden yang memiliki luas lahan $0,5-1,5 \mathrm{Ha}$ dan yang memiliki luas lahan >1,- $2 \mathrm{Ha}$.

\section{Metode Pengambilan Data}

Pengumpulan data dalam suatu penelitian bertujuan agar bahan atau data yang digunakan relevan. Data yang dipergunakan dalam penelitian ini meliputi data primer dan data sekunder.

\section{Data Primer}

Guna memperoleh data ini, maka penelitian ini menggunakan teknik:

a. Observasi

Observasi adalah cara dan teknik pengumpulan data dengan melakukan pengamatan dan pencatatan secara sistematis terhadap gejala atau fenomena yang ada pada obyek penelitian (Moh, 2005). Metode ini digunakan dalam rangka mencari data awal tentang daerah penelitian, untuk mendapatkan gambaran umum daerah penelitian dengan memperhatikan keadaan riil atau fenomena yang ada di lapangan.

b. Wawancara (Interview)

Wawancara merupakan metode pengumpulan data dengan cara tanya jawab yang dikerjakan dengan sistematis dan berlandaskan pada tujuan penelitian (Moh, 2005). Metode wawancara ini digunakan untuk memperoleh informasi tentang karakteristik responden dengan menggunakan kuesioner.

\section{Data Sekunder}

Data sekunder yaitu data yang diperoleh dari instansi-instansi yang berhubungan dengan masalah penelitian (instansi terkait), meliputi data fisik Desa Tikong dan data yang berhubungan dengan penelitian.

\section{Konsep Pengukuran Variabel}

Variabel-variabel yang akan diukur dalam penelitian ini adalah :

1. Luas lahan adalah luas yang digunakan dalam usahatani kakao $(\mathrm{Ha})$
2. Jumlah produksi kakao yaitu hasil produksi biji kakao $(\mathrm{Kg} / \mathrm{Ha})$

3. Harga jual biji kakao yang berlaku di tingkat petani pada saat pengambilan data (Rp)

4. Pendapatan usahatani adalah selisih antara penerimaan dan pengeluaran yang dinyatakan dalam rupiah $(\mathrm{Rp} / \mathrm{Ha})$. Sedangkan penerimaan adalah hasil kali antara jumlah produksi $(\mathrm{Kg})$ dengan harga jual (Rp) dinyatakan dalam $\mathrm{RP} / \mathrm{Kg} / \mathrm{Ha}$. Biaya produksi adalah biaya yang dikeluarkan oleh petani selama proses produksi berlangsung terdiri dari :

a. Biaya tetap atau (Fixed Cost) adalah biaya yang dikeluarkan oleh petani selama proses produksi berlangsung yang termasuk dalam biaya tetap yaitu biaya penyusutan alat yang digunakan dalam proses produksi seperti cangkul, sabit, gunting rumput, linggis ember dan karung.

b. Biaya variable (Variabel cost) yaitu biaya yang langsung mempengaruhi besarnya produksi yang dihasilkan , yang terdiri dari : biaya tenaga kerja $(\mathrm{Rp})$, biaya transportasi (Rp), dan biaya air (Rp).

5. Modal, meliputi jumlah modal dan sumber modal yang digunakan. Jumlah modal yaitu banyak modal yang digunakan dalam usahatani kakao. Sumber modal yaitu sumber kepemilikan modal antara lain berasal dari milik sendiri.

6. Penyusutan alat, yaitu nilai penggunaan alat disebabkan oleh pemakaianalat selama produksi .

7. Karakteristik petani

a. Umur petani

b. Status petani

\section{Metode Analisis Data}

Analisis data yang digunakan dalam penelitian ini adalah analisis deskriptif yang disajikan dalam bentuk tabel.

\section{HASIL DAN PEMBAHASAN}

\section{Deskripsi Umum Wilayah Penelitian}

Kabupaten Kepulauan Sula adalah salah satu kabupaten di Propinsi Maluku Utara,Indonesia. Kabupaten Kepulauan Sula 
dengan ibukota Sanana terletak paling Selatan di wilayah Propinsi Maluku Utara.Jarak dari Ibu Kota Propinsi sekitar $284 \mathrm{Km}$ dapat ditempuh melalui penerbangan udara dan pelayaran laut.Kabupaten Kepulauan Sula pada awalnya menjadi bagian dari Kabupaten Halmahera Barat, bersama-sama dengan Kabupaten Halmahera Utara dan Kabupaten Halmahera Selatan.

Kabupaten Kepulauan Sula terletak antara $01^{\circ}$ $45^{\prime}-00^{\circ} 00^{\prime} \mathrm{LS}$ dan $124^{\circ} 05^{\prime}-126^{\circ} 50^{\prime}$ BT. Kabupaten Kepulauan Sula terbagi menjadi 19 Kecamatan, 131 desa, dan 2 Unit Pemukiman Trans (UPT). Sebagai wilayah kepulauan yang terdiri dari 3 pulau (Pulau Sulabesi, Pulau Mangoli dan Pulau Taliabu)sebagian besar penduduk di Kabupaten Kepulauan Sula tinggal di sepanjang pesisir pantai.

\section{Karakteristik Petani Responden}

Tingkat umur mempengaruhi kemampuan seseorang dalam melakukan aktivitas maupun konsep berpikir khususnya untuk petani.Petani yang memiliki umur muda tentunya memiliki kondisi fisik yang kuat dan daya berpikir yang lebih kreatif dibandingkan dengan petani yang berumur tua.

\section{Pendidikan Responden}

Tingkat pendidikan yang dimaksud dalam penelitian ini adalah pendidikan formal yang diperoleh responden di bangku sekolah maupun perguruan tinggi. Pendidikan merupakan faktor yang dapat menentukan dan menambah pengetahuan seseorang utnuk mengerjakan sesuatu lebih cepat. Makin tinggi pendidikan seorang petani maka makin tinggi pula tingkat kecakapan dan fungsinya sebagai manejer, buruh tanu atau kepala rumah tangga.

\section{Jumlah Tanggungan Keluarga}

Jumlah tanggungan keluarga petani yang termasuk dalam tanggungan adalah yang membantu dalam usahatani keluarga dan yang tinggal atau sudah terhitung dalam keluarga itu sendiri. Jumlah tanggungan dalam keluarga petani responden dapat dilihat pada Tabel 5 . Tabel 5 menunjukan bahwa sebanyak 26 orang petani kakao atau $86.67 \%$ memiliki tanggungan 14 orang sedangkan yang memiliki tanggungan $13.33 \%$ adalah 4 orang petani responden.
Tabel 5. Jumlah Tanggungan Keluarga Petani

\begin{tabular}{lrr}
\hline $\begin{array}{c}\text { Tanggungan } \\
\text { dalam keluarga }\end{array}$ & $\begin{array}{c}\text { Jumlah } \\
\text { Petani } \\
\text { Responden }\end{array}$ & $\begin{array}{c}\text { Persentase } \\
(\boldsymbol{\%})\end{array}$ \\
\hline $1-4$ & 26 & 86,67 \\
$>4$ & 4 & 13,33 \\
\hline Jumlah & 30 & 100 \\
\hline
\end{tabular}

Sumber : Diolah dari data primer 2014

\section{Karakteristik Usahatani Kakao}

Karakteristik usahatani Kakao terdiri atas luas lahan dan modal. Luas lahan merupakan keseluruhan lahan ynag diolah petani sedangkan modal digunakan oleh peteni untuk memaksimalkan usahataninya.

\section{Luas Lahan}

Keseluruhan lahan yang diolah petani adalah milik sendiri dan digarap oleh petani itu sendiri.Luas lahan yang dimiliki petani sangat mempengaruhi besar kecilnya pendapatan karena akan berhubungan langsung dengan hasil produksi.Petani kakao di Desa Tikong Kecamatan Taliabu Utara Kabupaten Kepulauan Sula memiliki luas lahan yang beragam. Tabel 6 menunjukan luas lahan responden petani kakao di Desa Tikong.

Tabel 6. Luas Lahan Petani Kakao di Desa Tikong

\begin{tabular}{|c|c|c|}
\hline $\begin{array}{l}\text { Luas } \\
\text { Lahan } \\
\text { (Ha) }\end{array}$ & $\begin{array}{c}\text { Jumlah Petani } \\
\text { Responden } \\
\text { (Orang) }\end{array}$ & $\begin{array}{c}\text { Presentase } \\
(\%)\end{array}$ \\
\hline $0,5-1,5$ & 26 & 86.67 \\
\hline$>1,5-2$ & 4 & 13.33 \\
\hline Jumlah & 30 & 100 \\
\hline
\end{tabular}

Tabel 6 menunjukan bahwa sebagian besar petani responden menanam kakao dengan luas lahan 0,5 - 1,5 Ha sebanyak 26 petani atau $86,67 \%$ dari keseluruhan petani yang ada dan sisanya 4 petani atau $13,33 \%$ memiliki luas lahan sebesar >1,5 - 2 Ha. 


\section{Modal}

Modal yang digunakan responden usahatani kakao masing-masing berasal dari modal sendiri seperti kepemilikan lahan dan pohon kakao yang sudah ditanam dari orang terdahulu atau orang-orang sebelum mereka.Modal yang diperlukan untuk membayar peralatan-peralatan, tenaga kerja dan sewa angkutan. Seluruh responden memiliki modal sendiri.Sedikit banyaknya modal yang tersedia dalam proses usahatani tergantung dari besar lahan yang diusahakan.

\section{Produksi Dan Biaya Produksi}

Produksi adalah hasil yang diperoleh petani pada saat panen.Produksi merupakan output atau biji kakao kering yang di hitung dalam Kg dimana inputnya adalah bibit, cangkul, parang, penampung, karung dan tenaga kerja yang bisa memberikan keuntungan lebih kepada petani. Produksi usahatani kakao dapat dilihat pada Tabel 7.

Tabel 7. Rata Produksi Usahatani Kakao Per Luas Lahan

\begin{tabular}{ccc}
\hline $\begin{array}{c}\text { Luas } \\
\text { Lahan } \\
\text { (Ha) }\end{array}$ & $\begin{array}{c}\text { Jumlah Petani } \\
\text { Responden }\end{array}$ & $\begin{array}{c}\text { Rata-Rata } \\
\text { Produksi/ } \\
\text { Luas } \\
\text { Lahan } \\
(\mathbf{K g})\end{array}$ \\
\hline $0,5-1,5$ & 26 & 207.31 \\
$>1,5-2$ & 4 & 262.5 \\
\hline
\end{tabular}

Sumber : Diolah dari data

Primer 2014

Hasil penelitian menunjukan bahwa jumlah produksi biji kakao kering dengan luas lahan 1,5 - 2 Ha mempunyai rata-rata 262.5 $\mathrm{Kg} / \mathrm{Luas}$ Lahan sedangkan jumlah produksi dengan luas lahan 0,5 - 1,5 Ha mempunyai ratarata $207.31 \mathrm{Kg} / \mathrm{Luas}$ Lahandengan. Besarnya kecilnya produksi tergantung dari luas lahan yang dikelolah petani.

\section{a. Biaya Produksi.}

Dari hasil penelitian,usahatani kakao yang memiliki luas lahan $0,5-1,5 \mathrm{Ha}$ besarnya biayaproduksi rata-rata setahun sebesar $\mathrm{Rp}$ 159.260 sedangkan yang memiliki luas lahan $>1,5-2$ Ha besarnya biaya produksi rata-ata setahun sebesar Rp 120.802. Semua biaya yang dikeluarkan petani kakao untuk memproduksi hasil panen selama satu kali proses produksi atau masa tanam yang digolongkan dalam biaya tetap dan biaya variabel. Biaya produksi dalam usahatani kakao dibedakan menjadi dua macam, yaitn biaya tetap dan biaya variabel.Biaya tetap yang dikeluarkan oleh petani di Desa Tikong yaitu biaya penyusutan alatsedangka biaya variabel adalahtenaga kerja dan biaya transportasi pasca panen.

Biaya tetap adalah biaya tetap yang harus dikeluarkan pada berbagai tingkat output yang dihasilkan seperti biaya penyusutan alat, yaitu komponen biaya yang secara tidak langsung dikeluarkan petani.Biaya penyusutan dihitung dengan formulasi nilai beli alat dikalikan dengan jumlah alat sejenis, kemudian dibagi dengan umur ekonomis alat.Mengenai biaya tetap dapat dilihat dalam Tabel 8.

Tabel 8. Rata-Rata Biaya Produksi Usahatani Kakao Per Luas Lahan menurut Komponen biaya

\begin{tabular}{lcc}
\hline Jenis Biaya & \multicolumn{2}{c}{$\begin{array}{c}\text { Rata-rata Biaya } \\
\text { Produksi/Petani }\end{array}$} \\
\hline & $\begin{array}{c}\mathbf{0 , 5} \mathbf{- 1 , 5} \\
\text { Ha }\end{array}$ & $>\mathbf{1 , 5} \mathbf{- 2}$ Ha \\
$\begin{array}{l}\text { Biaya Tetap } \\
\text { Alat-alat }\end{array}$ & 44.333 & 45.802 \\
$\begin{array}{l}\text { Pertanian } \\
\text { Biaya }\end{array}$ & & \\
$\begin{array}{l}\text { Variabel } \\
\text { Tenaga Kerja }\end{array}$ & 33.077 & 62.500 \\
$\begin{array}{l}\text { Sewa } \\
\text { angkutan }\end{array}$ & 34.615 & 50.000 \\
\hline \multicolumn{1}{c}{ Rata-rata } & $\mathbf{1 1 2 . 0 2 6}$ & $\mathbf{1 1 3 . 3 0 2}$ \\
\hline Sumber: Ditat
\end{tabular}

Sumber : Diolah dari data primer 2014

Dari Tabel 8 dapat dilihat bahwa biaya produksi yang tertinggi dikeluarkan oleh petani terdapat pada kategori luas lahan >1,5 - $2 \mathrm{Ha}$ yaitu sebesar Rp. 113.302. Sedangkan biaya produksi pada kategori luas lahan 0,5 - 1,5 Ha hanya sebesar Rp. 112.026.

Biaya variabel adalah biaya yang berubah ubah menurut tinggi rendahnya tingkat pengeluaran.Biaya variabel merupakan jenis biaya yang dikeluarkan oleh petani jika kegiatan usahatani dijalankan.Biaya variabel usahatani kakao mencakup biaya yang dikeluarkan untuk tenaga kerja dan biaya transportasi pasca panen. 
Tabel 9. Luas Lahan, Rata-rata Produksi Harga Jual dan Penerimaan Usahatani

\begin{tabular}{ccccc}
\hline $\begin{array}{c}\text { Luas Lahan } \\
(\text { Ha) }\end{array}$ & Jumlah Responden & $\begin{array}{c}\text { Produksi } \\
(\mathbf{K g})\end{array}$ & $\begin{array}{c}\text { Harga Jual } \\
(\mathbf{R p})\end{array}$ & Penerimaan (Rp) \\
\hline $0,5-1,5$ & 26 & 207.31 & 10.577 & \\
$>1,5-2$ & 4 & 262.5 & 11000 & 2.864 .231 \\
\hline
\end{tabular}

Sumber : Diolah dari data primer 2014

\section{b. Transportasi}

Transportasi yang dimaksud adalah biaya distribusi hasil panen dari lahan tani ke pinggir jalan atau rumah, dan dari jalan raya menuju pasar. Transportasi yang digunakan untuk mengangkut hasil panen ke jalan raya atau rumah biasanya menggunakan sewa angkutan kuda, sedangkan untuk mengangkut dari rumah ke pasar,petani menggunakan gerobak. Biaya transportasi biasanya dihitung setiap sekali jalan, yaitu Rp. 50.000/angkut sehingga semakin banyak hasil panen maka semakin besar pula biaya transportasi.

\section{Penerimaan}

Total penerimaan yang dikeluarkan selama proses produksi berlangsung berdasarkan hasil penelitian, luas lahan, rata-rata produksi, harga jual dan rata-rata penerimaan dapat dilihat pada Tabel 9.

\section{Pendapatan Usahatani \\ Tenaga Kerja Dalam Kelurga}

Dalam penelitian ini, hampir semua tenaga kerja dalam keluarga selalu ada dalam tiap kegiatan. Tenaga kerja dari dalam keluarga merupakan sumbangan petani pada kegiatan produksi yang tidak di hitung atau dibayarkan. Pada tahap lainnya, sebagian petani menggunakan tenaga sendiri untuk mengerjakannnya sehingga tidak perlu mengeluarkan biaya tenaga kerja.

\section{Tenaga Kerja Luar Keluarga}

Digunakan pada tahap pemetikan dan pembelahan. Untuk kegiatan usahatani kakao di Desa Tikong, petani menggunakan tenaga kerja pada tahap pemetikan, pembelahan dan pada tahap panen. Biaya tenaga kerja berkisar Rp 50.000 / 3 jam kerja. Hasil penelitian menemukan bahwa pada beberapa tahap usahatani, upah tenaga kerja dibayarkan dengan sistem borong. Peggunaan tenaga kerja berdasarkan luas lahan 0,5 - 1,5 $\mathrm{Ha}$ dengan luas lahan>1,5 - $2 \mathrm{Ha}$ untuk 1 kali musim panen rata-rata mencapai 1-2 Orang. Sedangkan penggunaan jam kerja berdasarkan luas lahan 0,5 - 1,5 Ha dengan luas lahan $>1,5-2 \mathrm{Ha}$ untuk 1 kali musim panen rata-rata mencapai 1,9 per jam.

\section{Rata-rata Biaya Keseluruhan Usahatani Kakao}

Rata-rata keseluruhan biaya produksi usahatani kakao di Desa Tikong Kecamatan Taliabu Utara yang memiliki luas lahan 0,5 - 1,5 $\mathrm{Ha}$ atau rata-rata keseluruhan dari 26 petani dapat dilihat dalam Tabel 10.

Tabel 10. Biaya Keseluruhan 0,5 - 1,5 Ha atau dari 26 Petani

\begin{tabular}{clcc}
\hline No & $\begin{array}{c}\text { Biaya } \\
\text { Keseluruhan }\end{array}$ & Satuan & Nilai \\
\hline 1 & Luas Lahan & $\mathrm{Ha}$ & 20.5 \\
2 & Tenaga Kerja & $\mathrm{Rp}$ & 36.538 \\
3 & Sewa Angkutan & $\mathrm{Rp}$ & 34.651 \\
4 & Biaya Penyusutan & $\mathrm{Rp}$ & 44.333 \\
5 & Produksi & $\mathrm{Kg}$ & 207.31 \\
6 & Harga Jual & $\mathrm{Rp}$ & 10.577 \\
7 & Penerimaan & $\mathrm{Rp}$ & 2.864 .231 \\
8 & Biaya Prodksi & $\mathrm{Rp}$ & 159.26 \\
9 & Pendapatan & $\mathrm{Rp}$ & 2.009 .672 \\
\hline
\end{tabular}

Sedangkan Rata-rata biaya produksi usahatani kakao di Desa Tikong Kecamatan Taliabu Utara atau 4 responden yang memiliki Luas Lahan $>1,5-2 \mathrm{Ha}$ dapat dilihat dalam Tabel 11. 
Tabel 11. Rata-Rata Biaya Keseluruhan 1>1,5-2 Ha atau dari 4 Petani Responden

\begin{tabular}{clcc}
\hline No & $\begin{array}{c}\text { Biaya } \\
\text { Keseluruhan }\end{array}$ & Satuan & Nilai \\
\hline 1 & Luas Lahan & $\mathrm{Ha}$ & 1.88 \\
2 & Tenaga Kerja & $\mathrm{Rp}$ & 62.5 \\
3 & Sewa Angkutan & $\mathrm{Rp}$ & 50 \\
4 & Biaya Penyusutan & $\mathrm{Rp}$ & 45.802 \\
5 & Produksi & $\mathrm{Kg}$ & 262.5 \\
6 & Harga Jual & $\mathrm{Rp}$ & 11.000 \\
7 & Penerimaan & $\mathrm{Rp}$ & 2.887 .500 \\
8 & Biaya Prodksi & $\mathrm{Rp}$ & 120.802 \\
9 & Pendapatan & $\mathrm{Rp}$ & 2.766 .698 \\
\hline
\end{tabular}

\section{KESIMPULAN DAN SARAN}

\section{Kesimpulan}

Petani di Desa Tikong merupakan petani yang mengandalkan kemampuan atau teknik bertani tradisional, karena sebagian besar petani tidak memiliki tingkat pendidikan yang yang tinggi, dan kurang bahkan tidak pernah mengikuti penyuluhan pertanian. Pendapatan petani kakao di Desa Tikong Kecamatan Taliabu Utara Kabupaten Kepulauan Sula akan meningkat apabila petani sudah memiliki keahlian bercocok tanam produksi yang dihasilkan pun akan meningkat apabilan dijual dengan harga yang lebih tinggi.

\section{Saran}

1. Perlu adanya penyuluhan mengenai usahatani kakao untuk menambah pengetahuan petani tentang usahatani kakao.

2. Diperlukan pengusaha atau instansi yang terkai tuntuk memantau perkembangan dan budidaya kakao serta memberikan informasi secara kontinu tentang inovasi baru yang berguna bagi petani kakao.

3. Untuk meningkatkan pendapatan dalam usahatani kakao, diperlukan modal yang cukup besar maka perlu ada koperasi Desa untuk dapat memberikan bantuan kepada masyarakat.

\section{DAFTAR PUSTAKA}

Bambang., Yudi Ariyadi.2011. Sistem Agribisnis Terintegrasi Hulu- Hilir. Bandung
BAPPEDA, 2013Kabupaten Kepulauan Sula.

Departemen Pertanian Republik Indonesia. 2002. KarakteristikPetani Indonesia.Jakarta.

Hanafie, Rita.2010. Pengantar Ekonomi Pertanian. Yogyakarta

Loho, Yifiana.2008. Analisis Keuntungan Kerajinan Meubel Bambu Pada Kelompok Mandiri. Desa Tiwoho Kecamatan Wori

Miller dan Roger E. Meiners. 2000. Teori Mikro Ekonomi Intermediate, Penerjemah Haris Munandar. PT. Raja Grafindo Persada, Jakarta

Moehar, Daniel,.2012. Kakao Komoditas, Potensial Pengembangan Ekonomi Kerakyatan. Sumatera Barat

Moehar, Daniel., 2002. Pengantar Ekonomi Pertanian. PT Bumi Aksara, Jakarta

Moh, Pabunda Tika. 2005. Metode Penelitian Geografi. Jakarta : Bumi Aksara

Raja, O dkk. 2010.Kiat Sukses Mendirikan dan Mengelola UMKM. L Press, Jakarta.

Riyanto,Agus.2012.Analisis Keuntungan Dan Skala Usaha Peternakan Sapi Perah Rakyat Di Kota Semarang. Semarang

Ray-ray, Evangelista. 2013. Profil Usaha Bubur Jagung Mutiara di Malayang Satu Timur Manado. Skripsi Fakultas Pertanian

Sukirno, Sadono. 2008. Makro Ekonomi Teori Pengantar Edisi Ketiga. Jakarta

Sukirno, Sadono.2006. Mikro Ekonomi (Teori Pengantar). PT Raja Grafindo Persada, Jakarta.

Soekartawi.2002. Teori Ekonomi Produksi, dengan Pokok Bahasan Analisis Fungsi Cobb-Douglas. PT. Raja Grafindo Persada, Jakarta .

Soekartawi, 1995. Analisis Usahatani. UI. Jakarta

Sisno. 2001. Efisiensi Relatif Usaha Tani Tembakau Berdasarkan Perbedaan Luas Lahan Garapan, Tesis.Program Pasca Sarjana UGM Yogyakarta.

Sukirno, Sadono.2007. Makro Ekonomi. PT Raja Grafindo Persada, Jakarta.

Veronika, Wijayanti Reni.2010. Usahatani Kakao dan Tingkat Ekonomi Petani di Desa Banjarsari Kecamatan Kalibawang Kabupaten Kulon Progo. Yokyakarta

Yrama, Widya.2010. Pedoman Bertanam Cokelat "Tim Bina Karya'. Bandung

kepulauan 2008. Monografi kabupaten sula.Pay.www.kepsul.Malutprov.po.id/dawnloa d.php?id= 37. 21 juni 2012.Teori Permintaan (Demand) dan Teori Penawaran (Supply).http://www. ekomarwanto.com./teori-permintaan-demand-danteori.html

2013. Profil Umum Kabupaten Kepulauan Sula.http://BabII_Profil_Umum Kab_Kep. Sula. pdf.21Juni 2014. 